\title{
PROFESSIONAL ORIENTATION AND ENROLLMENT OF SECONDARY SCHOOL GRADUATES AT THE UNIVERSITY
}

\section{Sead Rešić ${ }^{1}$ \\ Hariz Agić}

Department of Mathematics of Natural Sciences, University of Tuzla

Pedagogy Institute of Tuzla Canton

Received: 29.08 .2013

Accepted: 05.09.2013
Original scientific paper

UDC: $373.5: 378.4-057.87(049.5)$

\begin{abstract}
Creating an environment for more efficient university education is closely related to effective planning, conducting and continuous improvement of realization of professional orientation program for students in elementary and secondary schools. The lack of personal vision of professional development for students in elementary and secondary schools, even several months before applying at university is defeating for the inputs in the process of higher education. The aim of this research was to evaluate the opinion of examinees - secondary school graduates (comprehensive schools, technical schools and those affine) - on issues regarding their intentions and decisions about continuing education, and to determine how these decisions were made. The analysis of gathered data revealed that the continuing of their education is not in sufficient accordance with their choice of secondary school. The results showed that the choice of current school and professional orientation program for students in elementary and secondary schools is not in accordance with their decision-making regarding continuing education at the university.
\end{abstract}

Keywords: career orientation, professional development, university education

\section{INTRODUCTION}

It is necessary to create admission policy in Bosnia and Herzegovina on the basis of justly established data concerning possible market demands, not only in the local community - canton, but to harmonize policies with other cantons, in order to avoid discordance at the expense of quality. New research could determine community interest in certain academic profiles that are lacking, as well as render the legislation flexible, so that university can respond to the challenges of change in the needs of the environment. This cannot be achieved without synergy with lower levels of education in the area of upbringing, education and timely professional orientation. This work presents experiences reached during research among secondary school graduates on the issue of the direction of their future professional development. Their decision to enroll at university is set in relation to their choice of secondary school or elected area of majors in case of comprehensive school, and their attitudes about the influences on their choice and, in general, knowledge about the very manners of studying. In short, the intention of this paper was to correlate students' professional orientation and their choice regarding future development.

\footnotetext{
${ }^{1}$ Correspondence to:

Sead Rešić, Department of Mathematics, Faculty of Natural Sciences, University of Tuzla

Sabana Zahirovića 10, Tuzla, B\&H

Phone: +38761101230

E-mail: sresic@hotmail.com
} 
Scientific literature claims that: "Professional orientation is a process which helps direct individuals towards those areas of work which suit their intellectual abilities, personal traits and professional interest best. Professional orientation is very important in the formation of adequate attitude towards work, creation of the professional spirit and satisfaction in future work. It is an important prerequisite for a successful future career. Successful career is tightly bound to wellchosen vocation."

This means that there should be a strong relation between students' dreams, their interest in particular subject matter, choice of adequate secondary school and subject majors in final grades and chosen university.

The subject of research in this paper is identification of graduates' attitudes regarding their intentions to continue education at a university, influences on decision-making, quality of their knowledge about studying in relation to their choice of secondary school.

The aim of research in this paper is to identify intensity of examinees attitudes - secondary school graduates - about intentions regarding their future vocation, whether they will continue education or not, about the manner and influences in decision-making for their future vocation, and ascertain whether there is significant statistical difference in opinions between comprehensive school graduates and those who attend technical and affine schools, regarding research questions, as well as to form certain conclusions and suggestions for improvement of professional orientation policy in secondary schools.

In a more concrete sense, aims of reasearch in this paper are:

- To determine the number of students who intend to enroll at the University of Tuzla in the academic year of 2012/2013.

- To determine to what extent examinees have already decided which university they will enroll.

- To determine to what extent their choice is consistent with the nature of their high school.

- To determine the degree of their familiarity with the nature of studying.

- Based on research results, bring forward appropriate conclusions and recommendations.

Reviewing literature and other information sources did not reveal existance of similar undertakes in other areas.
Thematics regarding accurate and timely professional orientation is topical nowadays. Education is ever more view through the financial prism (Trnavčević, 2002). That is why such education policy is necessary, which allows for respecting needs and affinities, as well as students' abilities on the one hand, and, on the other hand, vertical porosity in the professional sense - from choosing facultative majors in elementary schools, to the choice of secondary school and interest areas within those. It would be natural for students to enroll at the university for which they have acquired most competencies.

Hence, the reason for this research is to provide relevant indicators, which may help in making quality decisions, for authorities in education, in the segment of timely professional orientation, as well as for those responsible at universities, when it comes to efficient enrollment policy.

\section{METHODOLOGY OF THE RESEARCH}

In this paper, the traditional, empirical, analytical, quantitatively oriented, paradigm is used, on which Požarnikova (1999, p. 65) states that "in recent decades the world has experienced an important shift in the direction of qualitative research", especially in the field of education. Therefore, in this paper, quantitative approach is combined with descriptive method, which is more common to qualitative research approach. This has particularly come to light in the part of interpretation of statistical indicators. It is clear that neither paradigm is an advantage or a weakness, because as Mužić (1999, p.15) says, "there is no best paradigm." The approach in this paper is set up mainly relying on quantitative approach, because the opinions and convictions are obtained, to a greater extent, on the basis of quantitative data.

The task of research in this paper is to determine the relationship between professional orientation in high school (and earlier) and selecting students' preferred university.

Based on the statements above the hypotheses of this research are as follows:

H1. "There is no sufficient correlation between professional orientation in elementary and secondary school and intentions of continuing education at the university."

${ }^{2}$ www.centar-sirius.hr/index.php/orijentacija 
H2. "There is significant statistical difference in attitudes among comprehensive school graduates, and graduates of technical and related schools about their intentions, decision-making regarding the selection of their future university and in knowledge and topics of studying"

The sample. Bearing in mind the problem and goals of this research, even though it is impractical, nonfunctional and very expensive for researchers, comprehensive and extensive research of the whole basic set was conducted (i.e. $88 \%$ of the total number of graduates) in order to acquire answers to questions for examinees who could reliably "determine the distribution of certain behaviors, opinions and attitudes in the basic set" (Ristić, 2006, p.350). This was pos- sibile because the Pedagogical Institute of TK (Tuzla Canton), in which we work, has infrastructure which allows us to effectively reach all graduates and collect their views and opinions. We believe that the observation of the whole group of subjects - all graduates of secondary schools, and not one of its subsets (Mužić, 1979), enables a drastic increase of reliability and validity of research results, which makes the research more relevant.

Because of their specificity, we have separated high school graduates and technical school graduates (and graduates from Behram Bey's madrasa in Tuzla) to check whether there is a difference of opinion, depending on the separation. The sample is shown in Table 1.

Table 1. Research sample

\begin{tabular}{|c|c|c|c|}
\hline School type & $\begin{array}{l}\text { Number of } \\
\text { graduates }\end{array}$ & $\begin{array}{l}\text { Number of } \\
\text { examinees }\end{array}$ & Percentage \\
\hline High Schools in Tuzla Canton & 907 & 836 & $92,17 \%$ \\
\hline Tehnical schools (with madrasa) & 2740 & 2293 & $86,82 \%$ \\
\hline Religious school & 99 & 84 & $84,85 \%$ \\
\hline Total & 3647 & 3213 & $88,10 \%$ \\
\hline
\end{tabular}

The sample in this research was purposeful, because we took the set of all graduates from high school and secondary technical and related schools, who have an interest to think more intensively about future professional development. The sample is representative, considering that more than $88 \%$ of graduates completed the survey. This met the usual criteria, related to territoriality and school types, gender, etc. of the examinees. Thus, the sample which encompasses $88 \%$ of the basic set meets the expectations that it will be suitable "for obtaining the best knowledge and the most useful information." (Merriam, 1998, p. 61).

This research used a survey which Mužić (1999, p.82) identifies with the "process of simultaneous and written data collection from greater number of people (examinees) about something they know, feel or think."

A survey was conducted with questionnaires which consisted of combined closed and open questions. Examinees were offered to express to what degree they agree with offered statements, using Likert scale of assessment of attitudes.

The questionnaire consists of three parts.

The first part is used to gather information about the school examinee is attending or which elective courses are taken in comprehensive schools.

The second part of the questionnaire enables gathering information about the intentions of examinees to apply at university, desires, wishes, the degree of certainty of their intentions, and on school subjects that influenced the most their decision about their future professional development.

This section of the questionnaire enables examinees to openly declare the reasons why they will not apply at university.

Finally, the third part of questionnaire enables us to determine the intensity of agreement with offered statements by using the Likert scale about statements that speak about their beliefs and knowledge about university and studying, the statistics and perspective when it comes to their desired future vocation according to Employment Agencies, and so on. 
Limitations in the research were associated with a generalization. The sample in conducted research is representative and makes the vast majority of the basic set, chosen purposefully and as such enables generalization to the whole population in the area of Tuzla Canton. Generalization can also be used for the area of Bosnia and Herzegovina, because if we look at the constitutional structure of Bosnia and Herzegovina we can easily draw a conclusion that the educational dimensions are similar in all environments, which is something that authorities responsible for education in Bosnia and Herzegovina cannot be proud of.

\section{DATA PROCESSING}

While processing the data we used Windows tools. The collected data was summarized by attributes, expressed quantitatively and by percentage, and as such, for reasons of clarity, presented in tables and graphs. In the second part we particularly used method called AVM (Average Value Method), namely, the method of mean values (Walker, 2006). This method could be applied after the four degree Likert scale of assessment of attitudes was functionally connected with the numerical values of 2 to 5 .

Grade 2 indicates the lowest and 5 the highest level of satisfaction. After obtaining data which were assessed from 2 to 5 , it was possible to calculate the mean value of satisfaction in responses to each question or sub-question for both populations of examinees.

The resulting average values were used effectively for registration of any similarities and differences in levels of satisfaction of examinees from comprehensive school and technical school on the same issues. Finally, the results of responses of focus groups were compared on the same issues and were presented in tables and graphs.

\section{RESULTS OF THE RESEARCH}

\section{Professional orientation (PO)}

Comparing the type of school or elective courses in secondary schools with selecting universities, the resulting data are presented in Table 2.

Table 2. Professional orientation - indicators

\begin{tabular}{ccccc}
\hline Type of school & $\begin{array}{c}\text { Number } \\
\text { of } \\
\text { graduates }\end{array}$ & $\begin{array}{c}\text { Number } \\
\text { of } \\
\text { examinees }\end{array}$ & $\begin{array}{c}\text { Accordance } \\
\text { with PO }\end{array}$ & $\begin{array}{c}\text { The percentage of graduates } \\
\text { which have selected their } \\
\text { college in agreement with their } \\
\text { professional orientation }\end{array}$ \\
\hline $\begin{array}{c}\text { General } \\
\text { Secondary } \\
\text { school }\end{array}$ & 907 & 836 & 422 & $50,48 \%$ \\
Technical & 2641 & 2293 & 684 & $29,83 \%$ \\
school & & & & $50,00 \%$ \\
Madrasa & 99 & 84 & 42 & $35,73 \%$ \\
Total: & 3647 & 3213 & 1148 & \\
\hline
\end{tabular}

The fact that only $35.73 \%$ of graduates (1148 of 3213 surveyed students) decided to apply for university, which is consistent with the orientation in high school, says that importance of professional orientation was neglected throughout elementary and secondary school.

It can be concluded that the choice of their future vocation, to a greater extent, was more "correct" in comprehensive schools with $50.48 \%$, compared to a technical schools where nearly one in three students $(29.83 \%)$ made the "right" decision, i.e. chose the appropriate school in accordance with their preferences and desires, their personal vision. The data shows that elective courses in comprehensive schools did not achieve the goal, which was to timely affect the choice of future professional development of students. At the same time, the data on professional orientation in technical schools, says that the choice of future vocation in $2 / 3$ of cases is not in accordance with the nature of their secondary school.

This is a great lack of education system, which must not allow wandering, but help students to create their own, realistic, achievable vision of professional development. There is much room for analysis at the school level on the causes of this situation, and measures for improvement.

\section{The impact on professional status and decision-mak- ing on the future development of students}

We wanted to know who and to what extent, affects the students in making decisions about their professional development. 
Table 3. Influence on examinees in making decision on professional orientation

\begin{tabular}{lccccc}
\hline High schools in Tuzla Canton & \multicolumn{5}{c}{ Influence in professional orientation } \\
& $\begin{array}{c}\text { Number of } \\
\text { examinees }\end{array}$ & $\begin{array}{c}\text { Their } \\
\text { own } \\
\text { decision }\end{array}$ & $\begin{array}{c}\text { Parent } \\
\text { influence }\end{array}$ & $\begin{array}{c}\text { School/professor } \\
\text { influence }\end{array}$ & $\begin{array}{c}\text { Influence of } \\
\text { all subjects }\end{array}$ \\
\hline Comprehensive & & & & & \\
school & 836 & 631 & 40 & 2 & 145 \\
Technical schools & 2293 & 1717 & 145 & 89 & 374 \\
Madrasa & 84 & 65 & 3 & 0 & 16 \\
Total & $\mathbf{3 2 1 3}$ & $\mathbf{2 4 1 3}$ & $\mathbf{1 8 8}$ & $\mathbf{9 1}$ & $\mathbf{5 3 5}$ \\
In percentage & & $\mathbf{7 5 , 1 0 \%}$ & $\mathbf{5 , 8 5 \%}$ & $\mathbf{2 , 8 3 \%}$ & $\mathbf{1 6 , 6 5 \%}$ \\
\hline
\end{tabular}

The data obtained suggests that $3 / 4$ of students or $75.10 \%$ make their own decision about which university to attend.

It is unsettling to know the fact that the influence of parents $(5.85 \%)$ is rather insignificant, and even more defeating is the fact that the influence of schools, teachers, educational services has been reduced to a miserable $2.83 \%$, which means that the school does almost nothing for the vocational guidance of students, and that the students are left to themselves, to the influence of informal groups, associations, media and so on. Examinees $(16.65 \%$ of them) have confirmed that "all of those subject have a little" influence on them.

Thus, it can be concluded that schools are performing poorly when it comes to professional orientation of their students, and that it is necessary to examine how they use the lessons of a class community, and make changes to the Program of a class community in the area of working with students on their vision (self-) development.

\section{Admission to university}

In this section we showed the data concerning the intentions of students - high school seniors when it comes to possible admission to college, selection of specific faculties (the location and name of the faculty), and the reasons why students will not apply at university.

\section{Number of students who intend to apply at univer- sity}

We asked graduates whether they plan to apply at university after graduation. The answers were offered at different levels of agreement (Table 4).

Table 4. Intention to apply at university

\begin{tabular}{ccccc}
\hline Schools & $\begin{array}{c}\text { Number of } \\
\text { examinees }\end{array}$ & Definitely & Not sure & $\begin{array}{c}\text { Not } \\
\text { applying }\end{array}$ \\
\hline $\begin{array}{c}\text { General Secondary } \\
\text { schools }\end{array}$ & 836 & 779 & 44 & 5 \\
Technical schools & 2293 & 1245 & 714 & 337 \\
Madrasa & 84 & 80 & 4 & 0 \\
Total & 3213 & $\mathbf{2 1 0 4}$ & $\mathbf{7 6 2}$ & $\mathbf{3 4 2}$ \\
In percentage & & $\mathbf{6 5 , 4 8 \%}$ & $\mathbf{2 3 , 7 2 \%}$ & $\mathbf{1 0 , 6 4 \%}$ \\
\hline
\end{tabular}

Data shows that over $65 \%$ of students intend to apply at university. Comprehensive school students are a lot more certain (93\%) as opposed to "technicians" (54\%). This does not mean that these students are sure which university to apply at.

\section{Number of students who decided what they intend} to apply for

The data show that a very small number of graduates, three months before enrolling at university, know what they would like to apply for. 1440 students $(68.44 \%)$ out of the entire number of students who intend to study at university, or $44.81 \%$ out all examinees, know precisely what to study. 
Table 5. Display of number of students which have decided what they will study.

\begin{tabular}{ccccc}
\hline Schools & $\begin{array}{c}\text { Number of } \\
\text { examinees }\end{array}$ & Yes & No & Not sure \\
\hline General Secondary & 836 & 489 & 99 & 236 \\
schools & & & & \\
Technical schools & 2293 & 903 & 665 & 625 \\
Madrasa & 84 & 48 & 12 & 20 \\
Total & 3213 & $\mathbf{1 4 4 0}$ & $\mathbf{7 7 6}$ & $\mathbf{8 8 1}$ \\
\hline
\end{tabular}

The causes of this condition should be sought in further study, which would aim to determine why students are so late in making a decision about their future vocation. An important fact was that the 776 students from a total of 3213 examinees, or $24.15 \%$ of students do not want to study at all. Also, $881(27.42 \%)$ of all examinees are not sure what to study.

\section{How students look upon studying at university?}

The second group of questions was directed toward obtaining information regarding ideas examinees have about their 'future' university. The following text presents answers from the second group of questions in the questionnaire.

Examinees were offered a possibility to determine degree to which they agree with following statements:

a) I am familiar with the manner of studying

b) I am familiar with the manner of studying according to Bologna process

c) My choice of university is in accordance with my affinities, wishes and choice of secondary school

d) I understand the professional profile which is acquired upon graduating from university that I have chosen

e) I know that the Employment Bureau has a great number of registered unemployed graduates from the university I have chosen

f) I am not interested in the number of un/employed at the Employment Bureau

g) Are you familiar with subject matter that is studied at your chosen university?
Here is data acquired for every question:

The data suggests that high school students were much more informed than "technicians" when it comes to the way of studying (3.81\%:3.42\%). Therefore pedagogical school authorities should, in future work, know this fact and make the information program, which would introduce students efficiently on the way of studying, using resources from the environment (businessmen, professors, artists, etc.) Knowledge on methods of study (statement a) is one of the prerequisites for the proper decisions about their future professional development. Although the Bologna process is present at the University of Tuzla for four years now, there is not enough knowledge on that process outside the university.

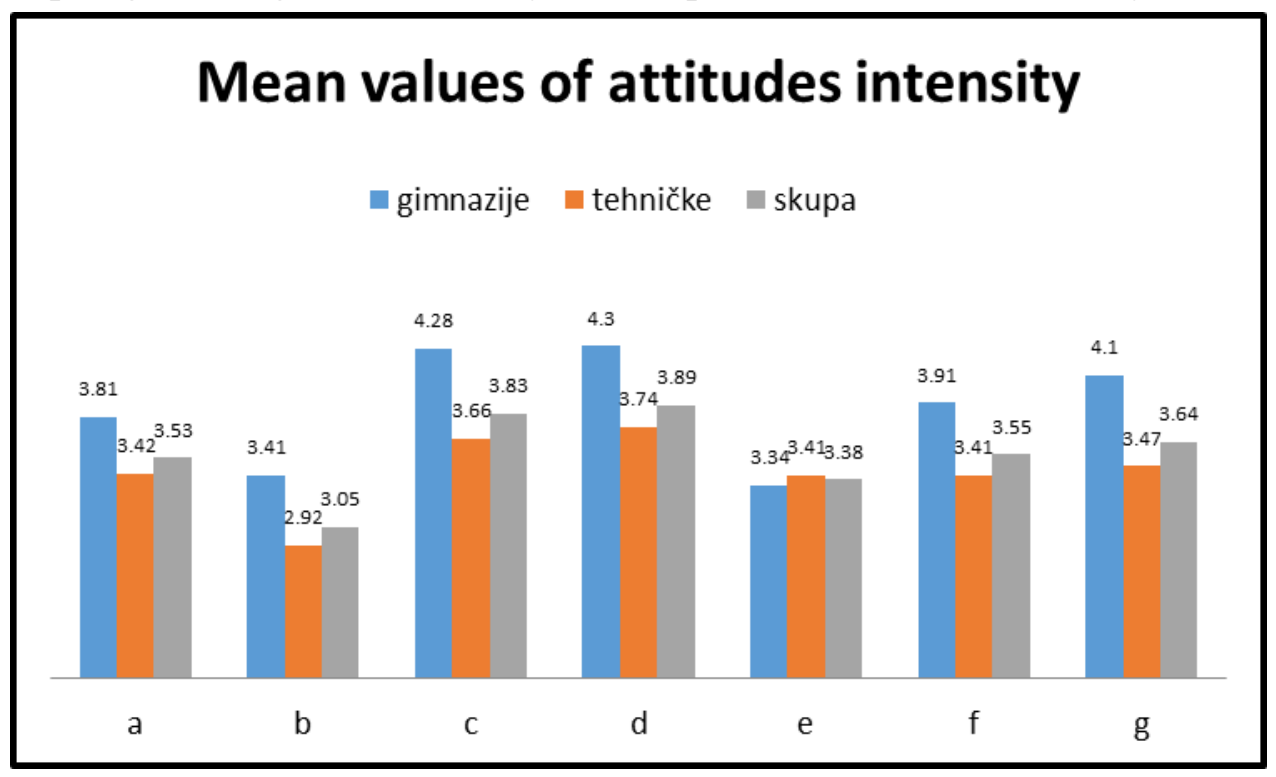

Graph 1. Data regarding replies to the second group of questions 
Data indicates that more than $66 \%$ of respondents are somewhat or not at all aware of the policy studies at Bologna process (statement b). Comprehensive school students are once again better informed (3.41:2.92). Average attitude of all examinees (3.05) on scale 2 -5 shows that level of knowledge of secondary school graduates is very low. Management of the University should keep in mind that Bologna process should be presented to their potential students. Benefits offered by full implementation of Bologna policies can be a definitive reason for making timely decisions about one's continuation of education. This could be an encouragement to university, education authorities and also schools to work in this direction. Even $27 \%$ (832 of 3099) students think that their choice of university (statement c) is not or is somewhat related to their, currently selected school. Attitudes of comprehensive school students are stronger than those of 'technicians' (4.28:3.42). This data is alarming because, in a sense, almost every third high school graduate, is wandering, and not only are they not sure if and what to study, but they, in university orientation, are changing their profession, and therefore, enter the high education unprepared, poorer without the necessary knowledge and skills to successfully continue their education and professional development. We were interested in data whether secondary school graduates know what is the final product and professional profile upon graduating university (statement d). Complete accordance with the statement was provided by $39.87 \%$ examinees, $48 \%$ comprehensive school students and $36.72 \%$ 'technicians'. The option 'somewhat' and 'not at all' was chosen by $24.96 \%, 14.83 \%$ comprehensive school students and $28.73 \%$ 'technicians'. When it comes to attitudes intensity, Graph 1 shows that it is higher in comprehensive school students (4.30:3.74). This is something to worry about, since almost every third student from technical schools wants to enroll at university without being sure, actually, what is hidden behind the diploma of their desired university. There is an ongoing debate between Employment Bureau and University regarding numbers of experts who gain knowledge at the University of Tuzla. That is why we were interested in information about data present among secondary school graduates regarding the state of affairs at the Employment Bureau (statement e). $24.46 \%$ graduates claim $100 \%$ agreement regarding knowledge about the state of affairs and structure of unemployed people at the Employment Bureau, 1 out of 4 students $(22.84 \%$ comprehensive school gradu- ates, $25.29 \%$ from technical schools). None or partial information is available to $46.65 \%$ examinees, or almost half of the graduates (52.27\% comprehensive school, 44.13\% technical schools). Everything can be changed by introducing the field of quality measurement (e.g., "progression to higher levels of education," or "Students enrolled in the desired college, which is consistent with the chosen school" (election areas in high school)). Then the high school, indeed, would have interest that their students are good college students, with high level of progression from the first to the second year, or have desirable success in entrance exam. Obviously, as before, here should get to synergy in the activity of universities, education authorities and schools. The fact that graduates want to enroll in college, and that doing so they know they will be registered at the Employment Agency, tells about the irrational decision making when it comes to choice of college. A flexible approach to the adoption of plans and programs, new academic departments, the introduction of a wide variety of areas of study, through choice of which students can gain immediate special references, required at the labor market, and might give better results when it comes to admissions policy. We wanted to know whether it is for the graduates, in general, important information from the employment agency. It turned out that $29.38 \%$ of all surveyed graduates or nearly every third respondent do not care for the data from the Employment Agency (statement f). Whereas, $40.52 \%$ of them say that the information on the status "of their profession" at the Employment Bureau is very interesting to them (attitude intensity ratio is 3.91:3.41 in favor of comprehensive school students). This can be a sign for participants interested in education, and employment agencies for launching a campaign aimed at informing about the state of the labor market and the need for certain staff, in Tuzla canton and beyond. Finally, we received information on whether respondents, in general, are familiar with the subject matter that is taught at university that graduates intend to enroll (statement g).

The survey showed that $23.68 \%$ of them are completely aware of what awaits them in university (4.10:3.47 in favor of comprehensive school students), while $33.08 \%$ of them do not have at all, or have little perception of attending courses at the desired faculty. Even here it was confirmed that the timely and accurate information is the not delivered. The education system should provide answers to these challenges. Concluding remarks will be given in the next section. 
It is no wonder that the University is not satisfied or, in recent years, disapproves (only informally though), the fact that student who come from high schools are not adequately prepared and interested in studying. Neither the University is interested in how schools are working, which are problems in secondary edu- cation, because the academic community is closed community (staff, assistants and assistant professors are recruited from within, few practitioners), and nor the schools have an interest in influencing students to make realistic, achievable decisions in their future development.

Table 6. Data on answers to second group of questions.

a) I am familiar with the ways of studying.

\begin{tabular}{lccccc}
\hline \multicolumn{1}{c}{ Schools } & $\begin{array}{c}\text { Number of } \\
\text { respondents }\end{array}$ & Completely & Mostly & A little bit & Not at all \\
\hline $\begin{array}{l}\text { General } \\
\text { Secondary }\end{array}$ & & & & & \\
school & 836 & 93 & 495 & 240 & 9 \\
Technical & 2293 & 211 & 964 & 836 & 208 \\
school & 84 & 6 & 46 & 32 & 0 \\
Madrasa & 3213 & 310 & 1505 & 1108 & 217 \\
Total & & & & & \\
\hline
\end{tabular}

b) I am familiar with studying policies according to Bologna process.

\begin{tabular}{cccccc}
\hline Schools & $\begin{array}{c}\text { Number of } \\
\text { respondents }\end{array}$ & Completely & Mostly & $\begin{array}{c}\text { A little } \\
\text { bit }\end{array}$ & $\begin{array}{c}\text { Not at } \\
\text { all }\end{array}$ \\
\hline $\begin{array}{c}\text { General } \\
\text { Secondary }\end{array}$ & 836 & 75 & 309 & 353 & 90 \\
school & & & & & \\
Technical & 2293 & 127 & 518 & 861 & 699 \\
school & & & & & \\
Madrasa & 84 & 2 & 28 & 35 & 18 \\
Total & 3213 & 204 & 855 & 1249 & 807 \\
\hline
\end{tabular}

c) My selection of college is in accordance with my affinities, desires and chosen high school.

\begin{tabular}{cccccc}
\hline & $\begin{array}{c}\text { Number of } \\
\text { respondents }\end{array}$ & Completely & Mostly & $\begin{array}{c}\text { A little } \\
\text { bit }\end{array}$ & $\begin{array}{c}\text { Not at } \\
\text { all }\end{array}$ \\
\hline General & 836 & 356 & 387 & 71 & 19 \\
Secondary school & & & & & \\
Technical school & 2293 & 722 & 730 & 402 & 330 \\
Madrasa & 84 & 27 & 43 & 9 & 3 \\
Total & 3213 & 1105 & 1160 & 482 & 352 \\
\hline
\end{tabular}


d) I understand the professional title that I acquire after the completion of my college.

\begin{tabular}{cccccc}
\hline Schools & $\begin{array}{c}\text { Number of } \\
\text { respondents }\end{array}$ & Completely & Mostly & A little bit & Not at all \\
\hline General & 836 & 402 & 311 & 89 & 35 \\
$\begin{array}{c}\text { Secondary } \\
\text { school }\end{array}$ & & & & & \\
Technical & 2293 & 842 & 673 & 357 & 302 \\
school & & & & & \\
Madrasa & 84 & 37 & 27 & 14 & 5 \\
Total & 3213 & 1281 & 1011 & 460 & 342 \\
\hline
\end{tabular}

e) I am familiar that there are many graduates from the college that I have chosen on unemployment list at the Employment Agencies.

\begin{tabular}{cccccc}
\hline Schools & $\begin{array}{c}\text { Number of } \\
\text { respondents }\end{array}$ & Completely & Mostly & $\begin{array}{c}\text { A little } \\
\text { bit }\end{array}$ & $\begin{array}{c}\text { Not at } \\
\text { all }\end{array}$ \\
\hline $\begin{array}{c}\text { General } \\
\text { Secondary school }\end{array}$ & 836 & 191 & 178 & 252 & 185 \\
Technical school & 2293 & 580 & 589 & 534 & 478 \\
Madrasa & 84 & 15 & 17 & 26 & 24 \\
Total & 3213 & 786 & 784 & 812 & 687 \\
\hline
\end{tabular}

f) I am not interested about the number of unemployed at Employment Agencies.

\begin{tabular}{cccccc}
\hline Schools & $\begin{array}{c}\text { Number of } \\
\text { respondents }\end{array}$ & Completely & Mostly & $\begin{array}{c}\text { A little } \\
\text { bit }\end{array}$ & Not at all \\
\hline $\begin{array}{c}\text { General } \\
\text { Secondary }\end{array}$ & 836 & 337 & 225 & 153 & 111 \\
school & & & & & \\
Technical & 2293 & 580 & 589 & 534 & 478 \\
school & & & & & \\
Madrasa & 84 & 27 & 28 & 17 & 9 \\
Total & 3213 & 944 & 842 & 704 & 598 \\
\hline
\end{tabular}

g) Are you familiar with the subjects that are taught at the faculty that you have chosen.

\begin{tabular}{cccccc}
\hline Schools & $\begin{array}{c}\text { Number of } \\
\text { respondents }\end{array}$ & Completely & Mostly & $\begin{array}{c}\text { A little } \\
\text { bit }\end{array}$ & Not at all \\
\hline $\begin{array}{c}\text { General } \\
\text { Secondary }\end{array}$ & 836 & 278 & 386 & 146 & 26 \\
school & & & & & \\
$\begin{array}{c}\text { Technical } \\
\text { school }\end{array}$ & 2293 & 462 & 812 & 556 & 360 \\
Madrasa & 84 & 21 & 35 & 23 & 2 \\
Total & 3213 & 761 & 1233 & 725 & 388 \\
\hline
\end{tabular}


Everything can be changed by introducing the field of quality measurement (eg, "progression to higher levels of education," or "Students enrolled in the desired college, which is consistent with the chosen school" (election areas in high school)). Then the high school, indeed, would have interest that their students are good college students, with high level of progression from the first to the second year, or have desirable success in entrance exam. Obviously, as before, here should get to synergy in the activity of universities, education authorities and schools. The fact that graduates want to enroll in college, and that doing so they know they will be registered at the Employment Agency, tells about the irrational decision making when it comes to choice of college. A flexible approach to the adoption of plans and programs, new academic departments, the introduction of a wide variety of electoral areas, the choice of which students can gain immediate special references, required at the labor market, and might give better results when it comes to admissions policy. We wanted to know whether it is for the graduates, in general, important information from the employment agency. It turned out that $29.38 \%$ of all surveyed graduates or nearly every third respondent do not care for the data from the Employment Agency. Whereas, $40.52 \%$ of them say that the information on the status "of their profession" at the Employment agency is very interesting to them. And this can be a sign for participants interested in educa- tion, and employment agencies for launching a campaign aimed at informing about the state of the labor market and the need for certain staff, at TK and beyond. Finally, we received information on whether respondents, in general, are familiar with the subject matter that is taught at colleges that graduates intend to enroll. The survey showed that $23.68 \%$ of them are completely aware of what awaits them in college, while $33.08 \%$ of them do not have at all, or have little perception of attending courses at the desired faculty. Even here it was confirmed that the information is the lifeblood. It is known that the informing, lack of communication at all levels, is a major state problem. The education system should provide answers to these challenges. Concluding remarks will be given in the next section.

\section{CONCLUSIONS AND RECOMMENDATIONS}

The research is valid, from the standpoint of basic group, the focus of research. It can be concluded that graduates from comprehensive secondary school more regularly attend classes, because the research was done randomly, without notice. $92.17 \%$ of them completed the questionnaire. The situation with the technicians is somewhat weaker because the total number of $86.82 \%$ of them filled out the questionnaire. A total of $88.10 \%$ of students underwent the survey, which is a sample that is more than representative for drawing valid conclusions.

Table 7. Professional orientation - indicators

\begin{tabular}{ccccc}
\hline Schools & $\begin{array}{c}\text { Number of } \\
\text { graduates }\end{array}$ & $\begin{array}{c}\text { Professional orientation } \\
\text { Number of } \\
\text { examinees }\end{array}$ & $\begin{array}{c}\text { Compliant with } \\
\text { professional } \\
\text { orientation }\end{array}$ & $\begin{array}{c}\text { Percentage of } \\
\text { correct } \\
\text { orientation }\end{array}$ \\
\hline $\begin{array}{c}\text { General } \\
\text { Secondary }\end{array}$ & 907 & 836 & 422 & $50,48 \%$ \\
$\begin{array}{c}\text { School } \\
\text { Technical } \\
\text { school }\end{array}$ & 2641 & 2293 & & \\
Madrasa & 99 & 84 & 684 & $29,83 \%$ \\
Total & $\mathbf{3 6 4 7}$ & $\mathbf{3 2 1 3}$ & 42 & $50,00 \%$ \\
\hline
\end{tabular}


Research has shown that there is a problem that arose as a result of lack of work with students on their professional orientation. These results, show that almost $2 / 3$ of students do not have their own vision, and that the situation is alarming and represents a huge loss to the education system of Tuzla canton, because the students are educated without a clear goal, which certainly affects the effectiveness and efficiency of the secondary, but also primary education, especially in the area of quality learning outcomes.

Results in the table are a clear sign that primary schools, and also secondary schools and technical schools, must make a very concrete steps to revitalize more active approach in process of professional orientation of students. This question must be answered by professionals (educational authorities and University).

This chaos in the area of professional orientation was confirmed by the results of the answers, which we got to the question "Who influences the students to decide on their future development."

It turns out that more than $3 / 4$ of students or $75.10 \%$ make their own decision about which university to attend. It is a troubling fact how insignificant influence of parents $(5.85 \%)$ really is on their decision, and even more defeating is the fact that the influence of schools, teachers, educational services have been reduced to a measly $2.83 \%$, which means that the school does almost nothing for the vocational guidance of students and that the students are left to themselves, to impacts of informal groups, associations, media and so on. Examinees (16.65\% of them) confirmed that "all of these subject have a little" influence on them.

Admission to university. The survey showed that nearly two thirds of examinees wanted to continue their education at the University. It is understandable that this percentage was higher in high school (comprehensive school) (93\%), while it was lower in technical schools (54\%).

Table 8. Orientation of respondents on studying intentions

\begin{tabular}{ccccc}
\hline Schools & $\begin{array}{c}\text { Number of } \\
\text { respondents }\end{array}$ & Definitely & Not sure & Not at all \\
\hline General & 836 & $779(93 \%)$ & 44 & 5 \\
Secondary & & & & \\
School & 2293 & $1245(54 \%)$ & 714 & 337 \\
Technical school & 84 & $80(95 \%)$ & 4 & 0 \\
Madrasa & $\mathbf{3 2 1 3}$ & $\mathbf{2 1 0 4}$ & $\mathbf{7 6 2}$ & $\mathbf{3 4 2}$ \\
Total & $\mathbf{1 0 0 \%}$ & $\mathbf{6 5 , 4 8 \%}$ & $\mathbf{2 3 , 7 1 \%}$ & $\mathbf{1 0 , 6 4 \%}$ \\
Percentage & &
\end{tabular}

It follows that every fifth examinee is unsure whether he or she will study. Our interest is the number of graduates who have decided what to study. So, of those 2104 graduates who have firmly decided to study, 1440 of them has a clear decision about what to study, in percentage $68.44 \%$. This data is closely related to poor treatment and the position of professional orientation. That kind of attitude is the cause of this condition. It is necessary to carry out further research, which aims to determine why students are so late in making a decision about their future vocation.
Based on the above it can be concluded that "there is not sufficient connection between the professional orientation in elementary and secondary school with intentions of continuing education at the university," which confirmed the first hypothesis. Thus, confirming that the schools are performing poorly on the professional orientation of students. It should be examined how the community classes are being used, and make changes to the class community Work Program in the area of working with students to help them create their vision of (self-) development 
The reason for not entering university. Important data, obtained in the study was that the 776 students from a total of 3213 examinees, or $24.15 \%$ of students do not consider studying at all. Examinees were able to comment and name reasons for not entering college. Most graduates believe that the cause of not continuing their education lies in: difficult economic situation, the lack of readiness for learning efforts, going abroad, poor grades, as well as the intent for employment or job search, but the lack of prospects and the crisis in employment after college as well.

Orientation for future faculty. From a review of data on graduates opting for a particular faculty, it is evident that most students choose the faculty of philosophy, economical faculty, medical, and legal, School of Electrical Engineering and Mining Geology and Geodesy Faculty. To make a proper decision on the Plan to enroll in colleges and universities study departments, it is necessary to carry out further research on trends in the number of candidates for admission to the University of Tuzla Canton outside the Tuzla Canton.

The results could be useful for the management of University in reform process in the creation of new scientific and educational fields, in creation of new flex- ible curricula with an emphasis on increased elective classes, where students, in accordance with their needs and the needs of the labor market, using the optional subjects, would be more able to create their future professional profile.

This should be an imperative and encouragement for the University, to use students' lack of interest for some study sections to strengthen creativity and flexibility to create educational programs that can respond to the present, and future needs of students, which includes the creation of new scientific and educational fields, more applicable, rather than theoretical, new profiles, orientations, which are popular in region, particularly in the European labor market.

Summarizing the results on the knowledge of graduates about studying. Finally, we were interested how graduates, future students behave toward studying, whether they have made the right decision entering certain faculty, whether they know what will they study, whether they know the situation at the Employment Bureau concerning employment rate of their future vocation and, in general, do they know the essence of the subjects which will be processed at selected study sections.

Table 9. Comparison of results - Comprehensive school vs. Technical schools

\begin{tabular}{cccccccc}
\hline & a & b & c & d & e & f & g \\
\hline $\begin{array}{c}\text { Comprehensive } \\
\begin{array}{c}\text { school } \\
\text { Technical } \\
\text { schools }\end{array}\end{array}$ & $\mathbf{3 , 8 0}$ & $\mathbf{3 , 2 3}$ & $\mathbf{4 , 3 0}$ & $\mathbf{4 , 2 9}$ & $\mathbf{3 , 4 7}$ & $\mathbf{3 , 9 5}$ & $\mathbf{4 , 1 0}$ \\
\hline
\end{tabular}

The above table and graph 2 present the cumulative results of the mean values of intensity of attitudes (AWM) in areas of the questionnaire concerning descriptive questions.

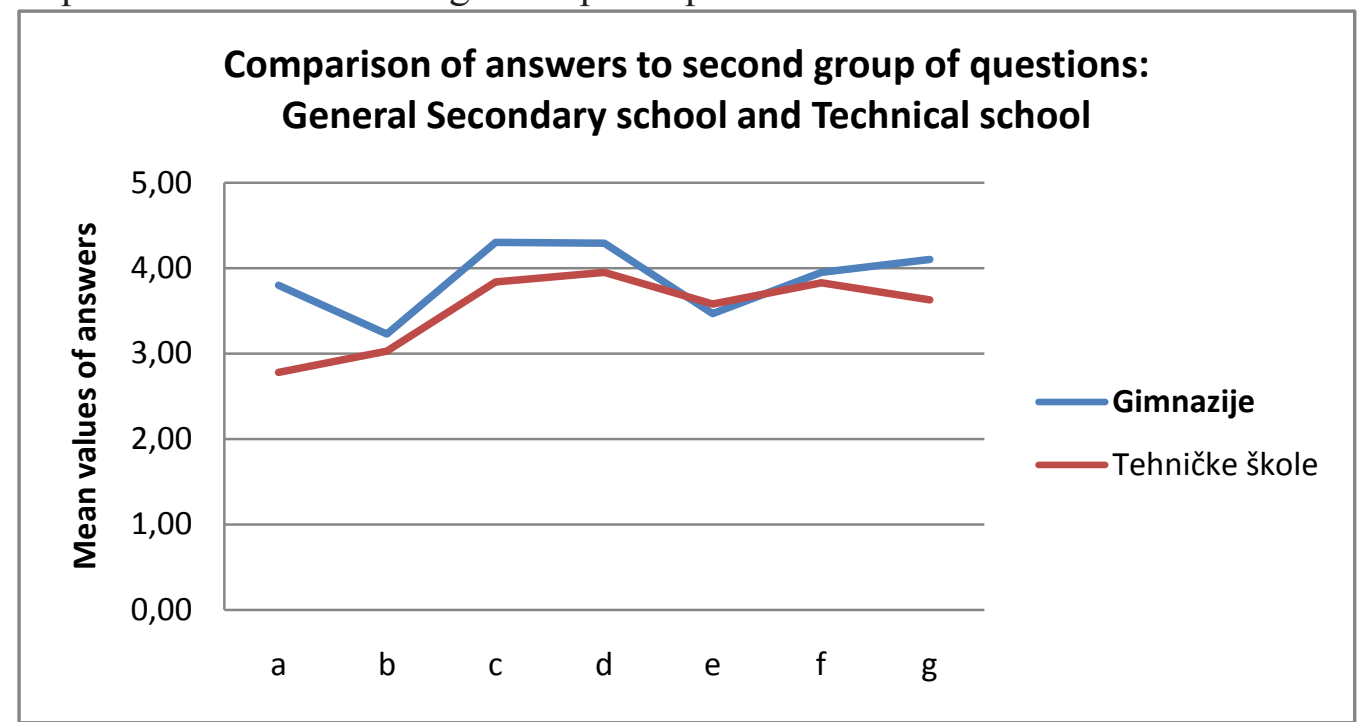

Graph 2. Comparison of results - General Secondary school vs. Technical schools 
It can be concluded that a higher degree of knowledge about the questions asked was at graduates from General Secondary school. Looking at the average value of the responses it can be seen that they move from 3.23 to 4.30 at graduates from GSS, and with the "technicians" from 2.78 to 3.95 , applying the inversion, it means that students are "mostly" familiar with determinants of the set. Based on the foregoing, second hypothesis can be confirmed, i.e. that "there is significant statistical difference in attitudes among graduates from GSS, and graduates of technical and related schools about the intentions, decision on selection of college and knowledge of subject matter."

\section{RECOMMENDATIONS}

Pedagogical authorities and schools should, if results of this research should be taken into account, create a work program with students, in the area of professional orientation toward their future vocation, according to their affinities and abilities.

Education authorities and establishments should work more on producing a more efficient system and forming students and teachers, so that their orientation and decision-making can be based on relevant information.

Elementary and secondary schools could modernize professional orientation programs, not only by following students' achievements and affinities, but learning about advantages and weaknesses certain professions, using human resources, school friends from the local community (engineers, teacher, managers etc.).

It is obvious that valid professional orientation does not only demand keeping pedagogical and professional records, but also the use of teacher-students conference classes should be examined, as well as changes in the work program of the class in the segment of work with students on building their vision and self-development.

In order for the University to make a more efficient contribution in professional orientation of students (about directing them toward chosen areas), quality cooperation should be established in the segment of classes with external experts, that will be useful not only in practical application of knowledge, but as an incentive for students to think about their future actively.

University must be interested in the way schools function, problems in secondary school education, be- cause the academic community is closed-up (teachers - employers are recruited from the inside, there are very few external experts), but also schools should do more to affect students to make realistic decisions about their future development.

Education authorities and the University should go decisively into change. The sooner the better. The changes are scientifically based and changes in practical experience in management may be of benefit to all honest agents of change (Agic, et al., 2006; 2007; 2009). There is a task for pedagogical staff of relevant educational authorities and schools, especially primary schools, to work more on encouraging students to create a realistic, achievable vision, using all the resources from the environment (successful entrepreneurs, representatives of public institutions, etc.). The research results can be helpful to all wellintentioned educators at all levels to pay attention to this very important issue: vocational guidance of students. Students do not necessarily need to be aware of it, but we, their teachers, certainly need to know that students need help to seek and find their way of professional development, as we were helped by our teachers.

\section{REFERENCES}

Agić, H. et al.. (2006). Vođenje u obrazovanju. Gradačac: JU Narodna biblioteka „Alija Isaković“" Gradačac

Agić, H. et. al. (2007). Organizacije i organizovanje u obrazovanju. Gradačac: JU Narodna biblioteka „Alija Isaković“ Gradačac

Agić, H. (2009). Djelatnost direktora i upravlajnje promjenama u obrazovanju. Doktorska disertacija. Novi Sad: Univerzitet u Novom Sadu, ACIMSI - Asocijacija Centara interdisciplinarnih i multidsciplinarnih studija i istraživanja.

Mužić, V. (1979). Metodologija pedagoškog istraživanja, IV izdanje, II prerađeno i nadopunjeno izdanje. Sarajevo: IGKRO „Savjetlost“"

Mužić, V. (1999). Uvod u metodologiju istraživanja odgoja $i$ obrazovanja. Zagreb: Educa

Ratković, M. (2000). Uspešan direktor škole. Strategije obrazovnih reformi. Beograd: Naučna knjiga i Centar za usavršavanje rukovodilaca u obrazovanju

Ristić, Ž. (2006). O istraživanju, metodu i znanju, drugo izdanje. Beograd: Institut za pedagoška istraživanja

Walker, R. (2006). AVM Testing: It Is Not as Daunting as You Might Think.

www.facorelogic.com, 25.08.2010.

Izvještaj o uspjehu i vladanju učenika srednjih škola TK na kraju 1. polugodišta školske 2011/2012. Pedagoški zavod Tuzlanskog kantona, februar 2012.

www.pztz.ba 